\title{
"STUDY OF COAGULATION PROFILE IN CLINICALLY DIAGNOSED CASES OF ACUTE DISSEMINATED INTRAVASCULAR COAGULATION USING ISTH CRITERIA"
}

Chopade S W'1, Phulgirkar P P², Hanmante R D³, Dhumure K S4, Bindu R S 5

\section{HOW TO CITE THIS ARTICLE:}

Chopade SW, Phulgirkar PP, Hanmante RD, Dhumure KS, Bindu RS. "Study of coagulation profile in clinically diagnosed cases of acute disseminated intravascular coagulation using ISTH criteria". Journal of Evolution of Medical and Dental Sciences 2013; Vol. 2, Issue 43, October 28; Page: 8240-8246.

ABSTRACT: Disseminated Intravascular Coagulation (DIC) is a pathological activation of coagulation (blood clotting) mechanisms that happens in response to a variety of diseases. It involves the generation of intravascular fibrin (small blood clots) and the consumption of pro-coagulants and platelets. It results in the disruption of normal coagulation mechanism and abnormal bleeding occurs from the skin, the gastrointestinal tract, the respiratory tract and surgical wounds. It was the prospective study of 60 patients of acute DIC, in which coagulation profile were studied from December 2010 to October 2012. 40 controls were studied. Control group include healthy voluntary blood donors. The coagulation profile was studied and DIC scoring was performed using the International Society on Thrombosis and Haemostasis [ISTH] criteria. Among the coagulation profile, the sensitivity and specificity of the parameters to diagnose and to assess the severity of DIC, in the decreasing order of frequency were of platelet count, D-dimer, PT and APTT. Fibrinogen level was not depleted below the significant level $(<1 \mathrm{gm} / \mathrm{l})$ in majority cases of DIC. According to the ISTH criteria, DIC scores among cases was $\geq 5$.

KEY WORDS: DIC, coagulation profile, ISTH, Platelet count, D-dimer.

INTRODUCTION: Disseminated Intravascular Coagulation (DIC) also known as consumptive coagulopathy, is a pathological activation of coagulation mechanisms that happens in response to a variety of diseases. [1] It is a systemic intravascular activation of the coagulation system, simultaneously leading to intravascular thrombi, compromising an adequate blood supply to the organ and to bleeding as consequences of exhaustion of the platelet and coagulation factors. [2], [3] The subcommittee on DIC of the International Society on Thrombosis and Haemostasis [ISTH] has suggested the definition for DIC: "An acquired syndrome characterized by the intravascular activation of coagulation with loss of localization arising from different causes. It can originate from and cause damage to the microvasculature, which if sufficiently severe, can produce organ dysfunction." [4] DIC is always secondary to an underlying disorder and is associated with a variety of clinical conditions. [5], [6] During this study, 60 patients with clinical diagnosis of Acute Disseminated Intravascular Coagulation (DIC) were included in the study as cases. The coagulation profile [PT, APTT, D-dimer, Fibrinogen and Platelet count] was studied and DIC scoring was performed using the International Society on Thrombosis and Haemostasis [ISTH] criteria. 
ORIGINAL ARTICLE

\begin{tabular}{|c|c|c|}
\hline Parameter & Value & Score \\
\hline \multirow{3}{*}{ Platelet count $(\mathrm{x} 10 \mathrm{3} / \mu \mathrm{l})$} & $>100$ & 0 \\
\cline { 2 - 3 } & $50-100$ & 1 \\
\cline { 2 - 3 } & $<50$ & 2 \\
\hline $\begin{array}{c}\text { Prothrombin time (sec) } \\
{[\text { prolongation by] }}\end{array}$ & $<3$ & 0 \\
\cline { 2 - 3 } & $>3$ but $<6$ & 1 \\
\hline \multirow{2}{*}{ Fibrinogen (gm/lit) } & $>6$ & 2 \\
\cline { 2 - 3 } & $>1 \mathrm{gm} /$ lit & 0 \\
\hline \multirow{2}{*}{$\begin{array}{c}\text { D-Dimer } \\
{[\text { Normal }-0.5 \mu \mathrm{g} / \mathrm{ml}]}\end{array}$} & No increase & 0 \\
\cline { 2 - 3 } & Moderate increase & 2 \\
\cline { 2 - 3 } & Marked increase & 3 \\
\hline
\end{tabular}

Table [1]. DIC Scoring System Using ISTH criteria: [7], [8]

\section{AIMS AND OBJECTIVES:}

1. To study the clinical profile in cases of Acute disseminated intravascular coagulation.

2. To study the intrinsic and extrinsic pathways of coagulation in clinically diagnosed cases of Acute disseminated intravascular coagulation, with the help of Prothrombin time and Activated Partial Thromboplastin Time.

3. To assess the fibrinolytic activity (using D-dimer assay) in clinically diagnosed cases of Acute disseminated intravascular coagulation.

4. To correlate the degree of impairment of various coagulation test results in cases of Acute disseminated intravascular coagulation.

5. To score the cases of Acute disseminated intravascular coagulation using ISTH criteria.

\section{INCLUSION AND EXCLUSION CRITERIA:}

INCLUSION CRITERIA: All patients clinically diagnosed as Acute DIC.

EXCLUSION CRITERIA: Patients other than Acute DIC with deranged coagulation profile.

MATERIAL \& METHODS: This prospective study was carried out in the department of pathology in the tertiary care institute during the period from December 2010 to October 2012. Cases were evaluated by routine haematological investigations and special tests like coagulation profile (PT, APTT, D-dimer and Fibrinogen assay). PT, APTT, and Fibrinogen tests were done on "Diagnostica stago coagulometer" as per manufacturer's instructions and guidelines. D-dimer assay was performed using D-di test (Latex agglutination test).

RESULT: During this study, the study population was 100. Of which 60 patients with clinical diagnosis of Acute Disseminated Intravascular Coagulation (DIC) were included in the study as cases and remaining 40 were included as control group. Control group includes the healthy voluntary blood donors. Among these 100 study population, 51(51\%) were male and 49 (49\%) were female with M:F ratio 1.04:1. Out of the 60 cases, 30 (50\%) were male and 30 (50\%) were female with M: F ratio 1:1. Age group in cases $[\mathrm{n}=60$ ] ranging from 03 days to 65 years with mean age 32 years. 
Among the 60 cases, there were various underlying conditions associated with Acute DIC. These are shown in Table [2].

\begin{tabular}{|l|c|c|}
\hline Underlying conditions & No. of cases & Percentage (\%) \\
\hline Septicemia & 21 & $35.00 \%$ \\
\hline Obstetric calamities & 20 & $33.33 \%$ \\
\hline Liver diseases & 06 & $10 \%$ \\
\hline Leukemia & 05 & $8.33 \%$ \\
\hline Snake bite & 04 & $6.67 \%$ \\
\hline Trauma & 04 & $6.67 \%$ \\
\hline Total & 60 & $100 \%$ \\
\hline
\end{tabular}

Table [2]. Underlying conditions associated with Acute DIC among cases $(n=60)$

\begin{tabular}{|c|c|c|c|c|c|c|}
\hline Parameter & $\mathrm{PT}$ (sec) & INR & $\begin{array}{l}\text { APTT } \\
(\mathrm{sec})\end{array}$ & $\begin{array}{l}\text { D-dimer } \\
(\mu \mathrm{g} / \mathrm{ml})\end{array}$ & $\begin{array}{c}\text { Fibrinogen } \\
(\mathrm{mg} / \mathrm{dl})\end{array}$ & $\begin{array}{l}\text { Platelet count } \\
\text { (/mm3) }\end{array}$ \\
\hline Min & 20.7 & 1.64 & 43 & \multirow{5}{*}{4 to 8} & 108 & 41000 \\
\hline Max & 38 & 4.08 & 63.4 & & 433 & 99500 \\
\hline Mean & 27.45 & 2.67 & 50.92 & & 244 & 76309 \\
\hline Median & 27.7 & 2.71 & 50.6 & & 234 & 77200 \\
\hline SD & 5.21 & 0.69 & 5.47 & & 86.15 & 18554 \\
\hline
\end{tabular}

Table [3]. Coagulation parameters of septicemic patients $(n=21)$

\begin{tabular}{|c|c|c|c|c|c|c|}
\hline Parameter & $\begin{array}{c}\text { PT } \\
(\mathrm{sec})\end{array}$ & INR & $\begin{array}{l}\text { APTT } \\
(\mathrm{sec})\end{array}$ & $\begin{array}{l}\text { D-dimer } \\
(\mu \mathrm{g} / \mathrm{ml})\end{array}$ & $\begin{array}{c}\text { Fibrinogen } \\
(\mathrm{mg} / \mathrm{dl})\end{array}$ & $\begin{array}{l}\text { Platelet count } \\
\text { (/mm3) }\end{array}$ \\
\hline Min & 23.4 & 2.15 & 44.3 & \multirow{5}{*}{$\begin{array}{c}4 \text { to } 8 \text { in } 18 \text { cases } \\
\& \\
>8 \text { in } 02 \text { cases. }\end{array}$} & 89 & 36,000 \\
\hline Max & 80 & 6.2 & 95.7 & & 353 & 99200 \\
\hline Mean & 34.34 & 3.08 & 55.07 & & 187 & 73595 \\
\hline Median & 27.85 & 2.63 & 49.75 & & 163 & 75,800 \\
\hline SD & 14.06 & 0.94 & 12.43 & & 85.48 & 18026 \\
\hline
\end{tabular}

Table [4]. Coagulation parameters of patients with Obstetrical calamities $(n=20)$

\begin{tabular}{|c|c|c|c|c|c|c|}
\hline Parameter & $\begin{array}{c}\mathrm{PT} \\
(\mathrm{sec})\end{array}$ & INR & $\begin{array}{r}\text { APTT } \\
(\mathrm{sec}) \\
\end{array}$ & $\begin{array}{l}\text { D-dimer } \\
(\mu \mathrm{g} / \mathrm{ml})\end{array}$ & $\begin{array}{c}\text { Fibrinogen } \\
\text { (mg/dl) }\end{array}$ & \begin{tabular}{|c|}
$\begin{array}{c}\text { Platelet count } \\
(/ \mathrm{mm} 3)\end{array}$ \\
\end{tabular} \\
\hline Min & 22 & 1.99 & 56.8 & \multirow{5}{*}{$\begin{array}{c}4 \text { to } 8 \text { in } 03 \text { cases } \\
\& \\
>8 \text { in } 03 \text { cases }\end{array}$} & 84 & 58000 \\
\hline Max & 70.3 & 5.44 & 98.5 & & 268 & 98200 \\
\hline Mean & 39.62 & 3.8 & 71.43 & & 155 & 77983 \\
\hline Median & 35.8 & 3.77 & 65.9 & & 151.5 & 82500 \\
\hline SD & 16.59 & 1.22 & 16.41 & & 70.01 & 16450 \\
\hline
\end{tabular}




\begin{tabular}{|c|c|c|c|c|c|c|}
\hline Parameter & $\begin{array}{c}\mathrm{PT} \\
(\mathrm{sec})\end{array}$ & INR & $\begin{array}{r}\text { APTT } \\
(\mathrm{sec})\end{array}$ & $\mathrm{D}$-dimer $(\mu \mathrm{g} / \mathrm{ml})$ & $\begin{array}{c}\text { Fibrinogen } \\
(\mathrm{mg} / \mathrm{dl})\end{array}$ & $\begin{array}{l}\text { Platelet count } \\
\text { (/mm3) }\end{array}$ \\
\hline Min & 18 & 1.55 & 43.5 & \multirow{5}{*}{$\begin{array}{c}4 \text { to } 8 \text { in } 03 \text { cases } \\
\& \\
>8 \text { in } 02 \text { cases }\end{array}$} & 79.8 & 14000 \\
\hline Max & 44 & 3.99 & 62.8 & & 147 & 68000 \\
\hline Mean & 28.82 & 2.6 & 51.82 & & 104 & 38000 \\
\hline Median & 24 & 2.22 & 46.8 & & 98 & 37000 \\
\hline SD & 11.33 & 1.05 & 8.96 & & 25.9 & 23717 \\
\hline
\end{tabular}

\begin{tabular}{|c|c|c|c|c|c|c|}
\hline Parameter & PT (sec) & INR & $\begin{array}{l}\text { APTT } \\
(\mathrm{sec})\end{array}$ & $\begin{array}{l}\text { D-dimer } \\
(\mu \mathrm{g} / \mathrm{ml})\end{array}$ & $\begin{array}{c}\text { Fibrinogen } \\
(\mathrm{mg} / \mathrm{dl})\end{array}$ & $\begin{array}{c}\text { Platelet count } \\
\text { (/mm3) }\end{array}$ \\
\hline Min & 22.8 & 2.07 & 43.9 & \multirow{2}{*}{4 to 8 in 1 case } & 124 & 80300 \\
\hline Max & 38.2 & 4.08 & 65 & & 390 & 98600 \\
\hline Mean & 29.8 & 2.97 & 53.75 & \multirow{3}{*}{$>8$ in 3 cases } & 215 & 87350 \\
\hline Median & 29.1 & 2.61 & 53.05 & & 174 & 85250 \\
\hline SD & 6.4 & 0.93 & 9.21 & & 118 & 8066 \\
\hline
\end{tabular}

\begin{tabular}{|c|c|c|c|c|c|c|}
\hline Parameter & $\begin{array}{c}\text { PT } \\
\text { (sec) }\end{array}$ & INR & $\begin{array}{l}\text { APTT } \\
(\mathrm{sec})\end{array}$ & $\begin{array}{l}\text { D-dimer } \\
(\mu \mathrm{g} / \mathrm{ml})\end{array}$ & $\begin{array}{c}\text { Fibrinogen } \\
(\mathrm{mg} / \mathrm{dl})\end{array}$ & $\begin{array}{l}\text { Platelet count } \\
\text { (/mm3) }\end{array}$ \\
\hline Min & 25.2 & 2.38 & 47.1 & \multirow{5}{*}{$\begin{array}{c}4 \text { to } 8 \text { in } 03 \\
\text { cases }\end{array}$} & 189 & 60000 \\
\hline Max & 29.2 & 2.87 & 54 & & 318 & 97500 \\
\hline Mean & 27.02 & 2.60 & 49.62 & & 251 & 85675 \\
\hline Median & 26.85 & 2.46 & 48.7 & & 250 & 92600 \\
\hline$\overline{S D}$ & 1.89 & 0.26 & 3.06 & & 62 & 17295 \\
\hline
\end{tabular}

Using the ISTH criteria, these 60 patients of acute DIC with different underlying conditions were assessed for DIC score. DIC score was found to be $>5$ (i.e. 5 - 8) in every case. Thus, this DIC score indicate that, laboratory evidences were consistent with DIC.

Out of the 60 cases, DIC score was found to be $\geq 5$ (i.e. 5 - 6) in 21 septicemic patients, $>5$ (i.e. 6 - 7) in 20 patients with obstetric calamities, $>5$ (i.e. 6 - 7) in the 06 patients with liver disease, $>5$ (i.e. 5 - 9) in the 05 patients with leukemia, $\geq 5$ (i.e. 5 - 6) among the 04 patients of snake bite and 5 in the 04 cases of traumatic history. Thus, DIC score was maximum among the patients with leukemia followed by obstetrical calamities and liver diseases. The highest DIC score was associated with the poor prognosis of the patients.

DISCUSSION: Disseminated intravascular coagulation is an acquired disorder that occurs in a wide variety of clinical conditions. It is characterized by the widespread activation of coagulation, which results in the intravascular formation of fibrin and ultimately thrombotic occlusion of small and midsize vessels. 
During the present study, out of 60 cases, septicemia accounting for 21 cases (35\%) was the most common condition associated with DIC. Septicemia was followed by obstetrical calamities, which accounts for 20 cases (33.33\%).

Neame P B et al. [9] (1974-1977) found 31 patients of septicemia and all were suffering from DIC. Lee J.H. et al. [10] (2000-2005) also found septicemia (as a single entity) was the predominant underlying condition leading to DIC.

\begin{tabular}{|c|c|c|c|c|c|c|c|c|c|}
\hline \multirow[b]{2}{*}{ Study } & \multirow[b]{2}{*}{ Year } & \multirow[b]{2}{*}{$\begin{array}{l}\text { No. of } \\
\text { cases }\end{array}$} & \multicolumn{7}{|c|}{ Underlying condition ( $\mathrm{n}=$ no of cases $\& \%$ ) } \\
\hline & & & 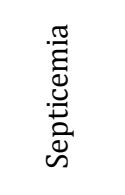 & 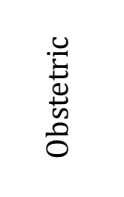 & 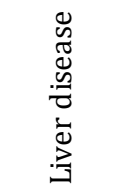 & 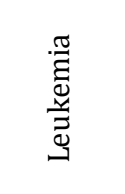 & 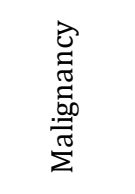 & 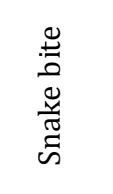 & 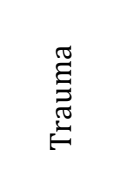 \\
\hline $\begin{array}{c}\text { Neame PB } \\
\text { et al. }{ }^{[9]}\end{array}$ & $1974-1977$ & 31 & 31 & -- & -- & -- & -- & -- & -- \\
\hline $\begin{array}{l}\text { Lee J.H. } \\
\text { et al. }{ }^{[10]}\end{array}$ & $2000-2005$ & $\begin{array}{c}131 \\
100 \% \\
\end{array}$ & $\begin{array}{c}42 \\
32.06 \% \\
\end{array}$ & $\begin{array}{c}04 \\
3.05 \% \\
\end{array}$ & $\begin{array}{c}18 \\
13.74 \% \\
\end{array}$ & -- & $\begin{array}{c}20 \\
15.27 \% \\
\end{array}$ & -- & $\begin{array}{c}04 \\
3.05 \% \\
\end{array}$ \\
\hline $\begin{array}{l}\text { Satoshi G. } \\
\text { et al.[11] }\end{array}$ & 2008 & $\begin{array}{c}329 \\
100 \%\end{array}$ & $\begin{array}{c}98 \\
29.79 \%\end{array}$ & $\begin{array}{c}04 \\
1.22 \%\end{array}$ & $\begin{array}{c}04 \\
1.22 \%\end{array}$ & -- & $\begin{array}{c}05 \\
1.52 \%\end{array}$ & -- & $\begin{array}{c}149 \\
45.29 \%\end{array}$ \\
\hline $\begin{array}{c}\text { Kaneko T. \& } \\
\text { Wada H.[7] }\end{array}$ & 2011 & $\begin{array}{l}1027 \\
100 \%\end{array}$ & $\begin{array}{c}244 \\
23.76 \%\end{array}$ & -- & $\begin{array}{c}101 \\
9.83 \%\end{array}$ & $\begin{array}{c}247 \\
24.05 \%\end{array}$ & $\begin{array}{c}402 \\
39.14 \%\end{array}$ & -- & -- \\
\hline Present study & $2010-2012$ & $\begin{array}{c}60 \\
100 \%\end{array}$ & $\begin{array}{c}21 \\
35 \%\end{array}$ & $\begin{array}{c}20 \\
33.33 \%\end{array}$ & $\begin{array}{c}06 \\
10 \%\end{array}$ & $\begin{array}{c}05 \\
8.33 \%\end{array}$ & -- & $\begin{array}{c}04 \\
6.67 \%\end{array}$ & $\begin{array}{c}04 \\
6.67 \%\end{array}$ \\
\hline
\end{tabular}

Table [9]. Comparison of studies according to underlying conditions associated with DIC

\begin{tabular}{|c|c|c|c|c|c|c|c|}
\hline Study & Year & $\begin{array}{l}\text { No. of } \\
\text { cases }\end{array}$ & $\begin{array}{c}\mathrm{PT} \\
\text { (\% of cases) }\end{array}$ & $\begin{array}{c}\text { APTT } \\
\text { (\% of cases) }\end{array}$ & $\begin{array}{c}\text { D-dimer } \\
\text { (\% of cases) }\end{array}$ & $\begin{array}{l}\text { Fibrin-ogen } \\
\text { (\% of cases) }\end{array}$ & $\begin{array}{l}\text { Platelet count } \\
\text { (\% of cases) }\end{array}$ \\
\hline $\begin{array}{l}\text { Colman } \\
\text { et al. [12] }\end{array}$ & 1972 & 48 & 90 & -- & -- & 71 & 93 \\
\hline $\begin{array}{c}\text { Al-Mondhiry et } \\
\text { al. [13] }\end{array}$ & 1975 & 89 & 87 & 62 & -- & 66 & 100 \\
\hline $\begin{array}{c}\text { Lewis } \\
\text { et al. [14] }\end{array}$ & 1977 & 215 & 72 & 65 & -- & 55 & 96 \\
\hline $\begin{array}{c}\text { Siegel } \\
\text { et al. [15] }\end{array}$ & 1978 & 118 & 98 & 93 & -- & 23 & 88 \\
\hline $\begin{array}{c}\text { Saxena R. } \\
\text { et al..16] }\end{array}$ & 2004 & 29 & 83 & 83 & 100 & -- & -- \\
\hline Present study & $2010-2012$ & 60 & 100 & 100 & 100 & 33 & 100 \\
\hline
\end{tabular}

The coagulation parameters of cases and controls were compared statistically using 'student T test.' The P value was obtained and it showed highly significant P value $(0.007)$ in terms of platelet count, $P$ value $(0.003)$ in terms of D-dimer. P values in terms of PT (0.04) and APTT (0.02) were also statistically significant. Thus, coagulation parameters in cases are consistent with clinical findings of DIC. The parameters like platelet count and D-dimer assay are the highly sensitive as well as specific marker for DIC. The parameters like PT and APTT showed linear correlation with DIC. The 
fibrinogen levels were variable and statistically were not highly significant as that of platelet count and D-dimer assay.

Although various laboratory assays have been used to diagnose Acute DIC, there is no single laboratory test currently available for accurate and precise diagnosis of acute DIC.

ISTH guidelines help to predict the severity and clinical outcome in DIC cases. DIC scoring using ISTH criteria, can diagnose the early DIC, which is beneficial for treating physician or surgeon to take prompt action in order to save the life of the patient.

CONCLUSION: DIC cases almost invariably associated with thrombocytopenia (moderate to severe) and increased D-dimer levels. Fibrinogen level was variable in Acute DIC cases so it is inconsistent parameter to assess Acute DIC.

Although various laboratory assays have been used to diagnose Acute DIC, there is no single laboratory test currently available for accurate and precise diagnosis of acute DIC. ISTH guidelines help to predict the severity and clinical outcome in DIC cases.

DIC scoring using ISTH criteria, can diagnose the early DIC, which is beneficial for treating physician or surgeon to take prompt action in order to save the life of the patient.

\section{REFERENCES:}

1. Saba H.I. and Morelli G. A. The pathogenesis and management of Disseminated Intravascular Coagulation, Clinical Advances in Haematology and Oncology, Dec 2006; Vol 4(12):919 - 26.

2. Dalainas. I. Pathogenesis, Diagnosis and management of disseminated intravascular coagulation: a literature review. European review for medical and pharmacological sciences, 2008; 12:19-31.

3. Levi M., Ten Cate H. Disseminated intravascular coagulation. N Engl J Med, 1999; 341: 586-92.

4. Taylor FBJ., Toh C.H., Hoots W.K., Wada H., Levi M., Scientific Subcommittee on Disseminated Intravascular Coagulation (DIC) of the International Society on Thrombosis and Haemostasis (ISTH). Towards definition, clinical and laboratory criteria, and a scoring system for disseminated intravascular coagulation. Thromb Haemost. Nov 2001; 86 (5):1327-30. [Medline].

5. Becker J.U. Disseminated Intravascular Coagulation in Emergency Medicine (emedicine.medscape.com/article/779097-overview)

6. Matsuda T. Clinical aspects of DIC--disseminated intravascular coagulation. Pol J Pharmacol. Jan-Feb 1996; 48(1):73-5. [Medline].

7. Kaneko T. and Wada H. Diagnostic Criteria and Laboratory Tests for Disseminated Intravascular Coagulation. Review Article, J Clin Exp, 2011; Hematopathol 51(2): 67-76.

8. Lehman et al. Analytic Validation and Clinical Evaluation of the STA LIA TEST Immunoturbidimetric D - Dimer Assay for the Diagnosis of Disseminated Intravascular Coagulation. American Journal of Clinical Pathology. 2004; 122:178-84.

9. Neame P.B. et al. Thrombocytopenia in septicemia: the role of disseminated intravascular coagulation. Blood journal haematology, 1980 56: 88-92.

10. Lee JH, Song JW and Song K. S. Diagnosis of Overt Disseminated Intravascular Coagulation: A Comparative Study Using Criteria from the International Society Versus the Korean Society on Thrombosis and Hemostasis: Yonsei Med J. 2007 August 31; 48(4): 595-600. 
11. Satoshi G. et al. Natural history of disseminated intravascular coagulation diagnosed based on the newly established diagnostic criteria for critically ill patients: Results of a multicenter, prospective survey. Crit Care Med 2008; Vol. 36, No. 1:145 - 50.

12. Colman RW, Robboy SJ and Minna, JD. Disseminated intravascular coagulation (DIC): an approach. American Journal of Medicine, 1972; 52,679 - 99.

13. Al-Mondhiry H. Disseminated intravascular coagulation. Experience in a major cancer centre. Thrombosis et Diathesis Haemorrhagica, 1975. 34,181-93.

14. Lewis JH, Spero JA. and Hasiba U. Coagulopathies Disease. 1977; 23, No. 9: 43 - 9.

15. SiegalT, Seligsoh U, Aghai E and Modan M. Clinical and laboratory aspects of disseminated intravascular coagulation (DIC): A study of 118 cases. Thrombosis and Haemostasis. (1978).

16. Saxena R. et al. D-dimer test: diagnostic role in clinical and sub-clinical DIC. Indian J Pathol Microbiol, 2003 Jul; 46(3):425 - 6.

\section{AUTHORS:}

1. Chopade S.W.

2. Phul girkar P.P.

3. Hanmante R.D.

4. Dhumure K.S.

5. Bindu R.S.

\section{PARTICULARS OF CONTRIBUTORS:}

1. Resident, Department of Pathology, Government Medical College, Aurangabad (Maharashtra).

2. Assistant Professor, Department of Pathology, Government Medical College, Aurangabad (Maharashtra).

3. Assistant Professor, Department of Pathology, Dr shankarrao chavan Government Medical College, Nanded (M aharashtra).
4. Resident, Department of Pathology, Government Medical College, Aurangabad (Maharashtra).

5. Professor and Head of the Department, Department of Pathology, Government Medical College, Aurangabad (Maharashtra).

\section{NAME ADDRESS EMAIL ID OF THE CORRESPONDING AUTHOR:}

Dr. Shreeram W. Chopade,

C/O Dr. R.D. Hanmante,

ND-42, A-1,2/8,

Danyan eshwar Nagar, CIDCO,

Nand ed (M aharashtra) - 431603.

Email - chopade.shriram@gm ail.com

Date of Submission: 03/10/2013.

Date of Peer Review: 04/10/2013.

Date of Acceptance: 15/10/2013.

Date of Publishing: 22/10/2013 